University of Nebraska - Lincoln

DigitalCommons@University of Nebraska - Lincoln

2008

\title{
Evaluation of Dry Distillers Grains Plus Solubles Inclusion on Performance and Economics of Finishing Beef Steers
}

C. D. Buckner

University of Nebraska, Lincoln

T. L. Mader

University of Nebraska Haskell Agriculture Laboratory, tmader1@unl.edu

G. E. Erickson

University of Nebraska-Lincoln, gerickson4@unl.edu

S. L. Colgan

University of Nebraska, Lincoln

D. R. Mark

University of Nebraska Haskell Agriculture Laboratory, Concord, NE

See next page for additional authors

Follow this and additional works at: https://digitalcommons.unl.edu/panhandleresext

Part of the Agriculture Commons

Buckner, C. D.; Mader, T. L.; Erickson, G. E.; Colgan, S. L.; Mark, D. R.; Bremer, V. R.; Karges, K. K.; and Gibson, M. L., "Evaluation of Dry Distillers Grains Plus Solubles Inclusion on Performance and Economics of Finishing Beef Steers" (2008). Panhandle Research and Extension Center. 47.

https://digitalcommons.unl.edu/panhandleresext/47

This Article is brought to you for free and open access by the Agricultural Research Division of IANR at DigitalCommons@University of Nebraska - Lincoln. It has been accepted for inclusion in Panhandle Research and Extension Center by an authorized administrator of DigitalCommons@University of Nebraska - Lincoln. 


\section{Authors}

C. D. Buckner, T. L. Mader, G. E. Erickson, S. L. Colgan, D. R. Mark, V. R. Bremer, K. K. Karges, and M. L. Gibson 


\title{
$\sqrt{17 r^{3}}$ \\ E

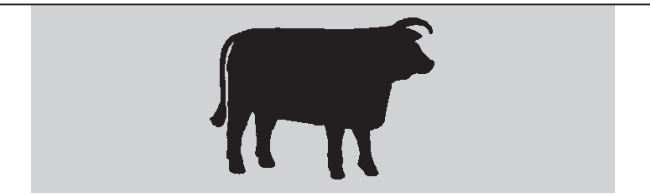 \\ Evaluation of Dry Distillers Grains Plus Solubles Inclusion on Performance and Economics of Finishing Beef Steers ${ }^{1}$
}

\author{
C. D. Buckner, ${ }^{\star}$ T. L. Mader,† G. E. Erickson, ${ }^{\star 2}$ S. L. Colgan, † D. R. Mark, † V. R. Bremer, K. K. \\ Karges,§ and M. L. Gibson§ \\ *Department of Animal Science, University of Nebraska, Lincoln 68583-0908; †University of \\ Nebraska Haskell Agriculture Laboratory, Concord, NE 68728-2828; ‡Department of Agricultural \\ Economics, University of Nebraska, Lincoln 68583; and §POET Nutrition, Sioux Falls, SD 57104
}

\begin{abstract}
A 167-d feedlot study was conducted to evaluate feeding increasing levels of dry distillers grains plus solubles (DDGS) to finishing cattle and the impact on performance and profitability. Crossbred steer calves $(n=240, B W$ $=306 \pm 24.5 \mathrm{~kg})$ were used in 30 pens with dietary treatments of 0,10,20, 30, and 40\% DDGS dietary inclusion (DM basis). Quadratic relationships $(P<0.05)$ were observed for final $B W$ and $A D G$ as dietary DDGS increased, with the greatest ADG observed at $20 \%$ inclusion. The DMI was not affected $(P>0.15)$ by DDGS level, but G:F tended to be quadratic $(P=0.10)$ as $20 \%$ DM inclusion had the greatest value, although steers fed all levels of DDGS had numerically greater G:F compared with steers fed no DDGS. Carcass characteristics, other than
\end{abstract}

\footnotetext{
${ }^{1} \mathrm{~A}$ contribution of the University of Nebraska Agricultural Research Division, supported in part by funds provided through the Hatch Act.

${ }^{2}$ Corresponding author: geericks@unlnotes. unl.edu
}

hot carcass weight, were not affected by DDGS treatment. Energy value of DDGS at 10 to 40\% dietary inclusion resulted in a quadratic trend $(P=0.10)$ and remained above corn, with the highest values at 10 and 20\% inclusion averaging $127 \%$ of corn. When DDGS was priced equally to corn, all levels of DDGS from 10 to $40 \%$ inclusion resulted in higher profits compared with a dry-rolled corn based diet regardless of corn price. The greatest returns were observed when cattle were fed $20 \%$ $D D G S$. These data indicate that DDGS can be fed up to 40\% DM to improve cattle performance and result in economic profits, with optimum levels at 20 to $30 \%$ diet DM.

Key words: cattle, dry distillers grains plus solubles, economics, finishing

\section{INTRODUCTION}

Ethanol production capacity has changed greatly in recent years with production capacity increasing about 3 -fold since 2000, and more increases are projected. As ethanol production increases, wet distillers grains plus solubles (WDGS) and dry distillers grains plus solubles (DDGS) production will increase as well (Stock et al., 2000). Distillers grains in finishing diets up to $15 \%$ of diet DM is primarily used as a protein supplement, and levels greater than 15\% are primarily fed as an energy source (Erickson and Klopfenstein, 2002). Vander Pol et al. (2006a) fed WDGS from 0 to $50 \%$ of diet DM and observed quadratic increases for ADG, DMI, and G:F, with optimum inclusion at 30 to $40 \%$ of diet DM. However, performance results have not been the same for feeding WDGS or DDGS (Ham et al., 1994). Previous research (Ham et al., 1994; Gordon et al., 2002; Benson et al., 2005; Vander Pol et al., 2008) has evaluated few inclusion levels of DDGS in finishing diets. Similar or slightly higher ADG and G:F were observed with DDGS compared with feeding a corn-based diet, but optimum inclusion level of DDGS has not been determined.

The objective of this experiment was to determine the effects of feeding increasing dietary inclusions of 
DDGS from 0 to $50 \%$ on finishing cattle performance, carcass characteristics, and economic returns.

\section{MATERIALS AND METHODS}

\section{Feedlot Trial}

A 167-d finishing study was conducted using 240 crossbred, backgrounded steer calves (306 \pm $24.5 \mathrm{~kg}$ ) in a randomized completeblock design experiment. Steers with ample bunk space were limit-fed a receiving diet containing $30 \%$ alfalfa hay, 20\% corn silage, 30\% DDGS, 14\% dry-rolled corn (DRC), and

\section{Table 1. Composition of final finishing diets and nutrient analysis for dietary treatments ${ }^{1}$}

\begin{tabular}{|c|c|c|c|c|c|}
\hline \multirow[b]{2}{*}{ Item } & \multicolumn{5}{|c|}{$\%$ DDGS $^{2}$} \\
\hline & 0 & 10 & 20 & 30 & 40 \\
\hline \multicolumn{6}{|l|}{ Ingredient } \\
\hline Dry-rolled corn & 79.5 & 70.5 & 61.5 & 51.5 & 41.5 \\
\hline DDGS & 0.0 & 10.0 & 20.0 & 30.0 & 40.0 \\
\hline Corn silage & 10.0 & 10.0 & 10.0 & 10.0 & 10.0 \\
\hline Alfalfa hay & 2.5 & 2.5 & 2.5 & 2.5 & 2.5 \\
\hline Liquid supplement & 6.0 & 6.0 & 6.0 & 6.0 & 6.0 \\
\hline Limestone & 1.55 & 1.55 & 1.55 & 1.55 & 1.55 \\
\hline Salt & 0.3 & 0.3 & 0.3 & 0.3 & 0.3 \\
\hline Trace mineral $^{3}$ & 0.05 & 0.05 & 0.05 & 0.05 & 0.05 \\
\hline Vitamins $A, D$, and $E$ & 0.02 & 0.02 & 0.02 & 0.02 & 0.02 \\
\hline Monensin-80 premix ${ }^{4}$ & 0.02 & 0.02 & 0.02 & 0.02 & 0.02 \\
\hline Thiamine premix ${ }^{5}$ & 0.01 & 0.01 & 0.01 & 0.01 & 0.01 \\
\hline Tylosin-40 premix ${ }^{6}$ & 0.01 & 0.01 & 0.01 & 0.01 & 0.01 \\
\hline Dry supplement & 2.0 & 1.0 & 0.0 & 0.0 & 0.0 \\
\hline Fine ground corn & 0.85 & 0.43 & - & - & - \\
\hline Urea & 1.15 & 0.57 & - & - & - \\
\hline \multicolumn{6}{|l|}{ Dietary nutrient analysis ${ }^{7}$} \\
\hline $\mathrm{CP}, \%$ & 13.2 & 13.8 & 14.4 & 16.5 & 18.6 \\
\hline $\mathrm{Ca}, \%$ & 0.78 & 0.78 & 0.79 & 0.79 & 0.80 \\
\hline $\mathrm{P}, \%$ & 0.28 & 0.34 & 0.39 & 0.44 & 0.49 \\
\hline $\mathrm{K}, \%$ & 0.59 & 0.68 & 0.78 & 0.87 & 0.96 \\
\hline S, \% & 0.15 & 0.24 & 0.33 & 0.41 & 0.50 \\
\hline Ether extract, \% & 3.53 & 4.35 & 5.17 & 5.95 & 6.73 \\
\hline
\end{tabular}

${ }^{1}$ Values presented on \%DM basis.

${ }^{2} \mathrm{DDGS}=$ dry distillers grains plus solubles.

${ }^{3}$ Supplemental trace minerals providing $50 \mathrm{mg} / \mathrm{kg} \mathrm{Mg}, 30 \mathrm{mg} / \mathrm{kg} \mathrm{Zn}, 22.5 \mathrm{mg} / \mathrm{kg} \mathrm{Fe}$, $10 \mathrm{mg} / \mathrm{kg} \mathrm{Mn}, 2.5 \mathrm{mg} / \mathrm{kg} \mathrm{Cu}, 1.5 \mathrm{mg} / \mathrm{kg} \mathrm{I}$, and $0.3 \mathrm{mg} / \mathrm{kg}$ Co of the diet.

${ }^{4}$ Premix provided a target of $320 \mathrm{mg} / \mathrm{steer}$ daily monensin.

${ }^{5}$ Premix provided a target of $150 \mathrm{mg} / \mathrm{steer}$ daily thiamine.

${ }^{6}$ Premix provided a target of $90 \mathrm{mg} / \mathrm{steer}$ daily tylosin.

${ }^{7}$ Dietary nutrient analysis utilizing analyzed values for CP, P, S, and ether extract of each ingredient. Calcium and $\mathrm{K}$ were calculated from book values.
University of Nebraska Haskell Agriculture Laboratory at Concord, $\mathrm{Ne}$ braska. All animal care procedures were approved by the University of Nebraska's Institute for Animal Use and Care Committee.

Dietary treatments (Table 1) consisted of control (CON) with $0 \%$ DDGS, or $10,20,30,40$, or $50 \%$ DDGS on a DM basis. All DDGS was obtained as needed (approximately once per month) from POET Nutrition (Sioux Falls, SD) and sampled individually for sulfur content. Inclusion of DDGS in the diets replaced DRC and supplemental protein. The CON and 10\% DDGS diets included 2 and $1 \%$ dry supplement, respectively, which provided supplemental urea to meet a minimum dietary $\mathrm{CP}$ of $13 \%$. All diets contained $10 \%$ corn silage (approximately 50\% roughage) and $2.5 \%$ ground alfalfa hay to provide about $7.5 \%$ roughage. Diets also contained $6 \%$ liquid supplement that included $\mathrm{Ca}$, monensin $(320 \mathrm{mg} /$ steer daily; Elanco Animal Health, Greenfield, IN), thiamine (150 mg/ steer daily), and tylosin (90 mg/steer daily, Elanco Animal Health). All diets met or exceeded metabolizable protein requirements (NRC, 1996).

Steers were adapted to finishing diets over a 22 -d period as 3 diet steps were fed for 7,7 , and $8 \mathrm{~d}$, for which DRC increased in diets and alfalfa hay levels decreased at levels of 30 , 20 , and $10 \%$, respectively. Inclusion level of DDGS remained the same throughout the adaptation period to the final finishing diets. Steers were fed ad libitum at $0800 \mathrm{~h}$ and offered ad libitum access to water.

Steers were implanted initially on d 0 with Ralgro (Schering-Plough Animal Health, Kenilworth, NJ) and re-implanted on d 56 with RevalorS (Intervet, Millsboro, DE). Feed ingredient samples were collected once every $2 \mathrm{wk}$, analyzed for DM at $60^{\circ} \mathrm{C}$ for $48 \mathrm{~h}$, and composited by sample type over the feeding period for nutrient analysis. Analyzed nutrients included CP (AOAC, 990.03), fat (AOAC, 920.39), phosphorus (AOAC, 968.08 and 965.17), and 
sulfur (AOAC, 968.08; Tinsdale et al., 1985).

High total dietary S levels of $0.6 \%$ with the 50\% DDGS treatment contributed to some polioencephalomalacia (PEM). By d 22 of the trial, there were 6 steers that exhibited symptoms and were treated for PEM and removed from their pens, with 5 of the steers from the $50 \%$ DDGS treatment, and 1 from the $40 \%$ DDGS treatment. Therefore, all steers on the $50 \%$ DDGS treatment were removed from the study.

Steers were slaughtered on d 168 at a commercial abattoir (Greater Omaha Pack, Omaha, NE) where hot carcass weight (HCW) and liver scores were recorded on day of slaughter. Fat thickness and LM area were measured, and \% KPH and USDA marbling scores were recorded after a 48-h chill. Hot carcass weight, fat thickness, LM area, and KPH were used to calculate USDA YG as follows: $2.50+6.35 \times$ fat thickness $(\mathrm{cm})+0.0017 \times \mathrm{HCW}(\mathrm{kg})-2.06 \times$ LM area $\left(\mathrm{cm}^{2}\right)+0.2 \times \mathrm{KPH}(\%$; Boggs and Merkel, 1993). Final BW, ADG, and G:F were calculated based on $\mathrm{HCW}$ and were adjusted to a common dressing percentage of $63 \%$ to minimize error associated with gut fill and to obtain an accurate estimate of final BW. Dressing percentage tended to be quadratic $(P=0.08)$ with greater HCW (i.e., greater dressing percentage) for steers fed DDGS compared with corn. Therefore, final live BW are provided as well.

Calculated net energy for gain was estimated using a model developed by Owens et al. (2002). This model uses iterative equations accounting for pen-level ADG, DMI, G:F, and percent DDGS to calculate the energetic responses due to DDGS inclusion. Energy values for DDGS were calculated using the CON diet as the basis at $100 \%$.

Some pens of cattle were observed to be moving feed around or tossing feed out of their bunks late in the finishing period. A 4-point (0 to 3) visual scoring system was used on 5 random days within the last month of the trial to determine any relationships between behavior at the feed bunk and level of DDGS fed. Scores used were 0 for no feed movement, 1 for little feed moved around inside the bunk, 2 for feed moved within the bunk and little feed pushed over the bunk walls, and 3 for a significant amount of feed moved within the bunk and some feed tossed over the bunk walls onto the feed alley.

Performance and carcass data were analyzed as a randomized completeblock design using the mixed procedures of SAS (Version 8.02, SAS Inc., Cary, NC) with pen as the experimental unit and block as a fixed effect. Orthogonal contrasts were used to test significance $(P<0.05)$ for the highest order polynomial. Feeding behavior data were analyzed with the chi-square procedures of SAS.

\section{Economic Analysis}

Performance Inputs. Response equations for DMI and G:F from this experiment were used to predict biological performance for feeding increasing dietary amounts of DDGS from 0 to $40 \%$ (DM basis). Steers fed the corn-based diet were used as a baseline to predict feedlot cattle performance when feeding DDGS, which included $9.25 \mathrm{~kg}$ DMI and $0.162 \mathrm{G}$ :F for cattle fed corn. Initial $(307 \mathrm{~kg})$ and final $(558 \mathrm{~kg}) \mathrm{BW}$ for cattle fed the corn-based diet were also used, which remained constant across all levels of DDGS. Biological DMI and G:F were estimated from prediction equations assuming a quadratic relationship with the equations generated from Microsoft Excel (Microsoft, Redmond, WA) for feeding 10, 20, 30, and 40\% DDGS (DM basis). Gain and days on feed were calculated assuming equal final BW to that of steers fed the corn-based diet. Total yardage costs ( $\$ 0.35 /$ head daily) were divided into 2 parts: nonfeeding costs at two-thirds and feeding costs at one-third of total yardage costs. Processing and medical expenses, death loss, and cattle loan interest remained constant for any DDGS scenario analyzed at
$\$ 20.00 /$ head, $1.5 \%$, and $8.1 \%$, respectively, as minimal health challenges were observed for steers fed 0 to $40 \%$ DDGS. This approach is a modified version of the economic analysis that Vander Pol et al. (2006b) conducted for feeding WDGS.

\section{Feed Ingredient Prices and} Transportation Costs. Dry distillers grains plus solubles were evaluated at 80 or $100 \%$ the price of corn (DM basis) at the ethanol plant with 1 of 3 different corn prices, resulting in 6 scenarios. Price of DDGS relative to corn is elusive, but USDA Agricultural Marketing Service price reports suggest a range between 80 and 100\% (or more) the price of corn on a DM basis. Therefore, both pricing scenarios were evaluated for DDGS price relative to corn (DM basis). Alfalfa hay, dry supplement, and urea costs were $\$ 0.033, \$ 0.045$, and $\$ 0.073 / \mathrm{kg}$ of DM, respectively. Alfalfa hay $(88 \%$ DM) and dry supplement (95\% DM) remained constant in all diets at 7 and $6 \%$ of diet DM, respectively. Urea (100\% DM) inclusion (part of the dry supplement inclusion) and pricing was only used if diets needed supplemental protein to meet a minimum $13 \% \mathrm{CP}$ diet (i.e., for $\mathrm{CON}$ and 10\% DDGS). Inclusions of DDGS used were 0,10,20,30, and $40 \% \mathrm{DM}$, and the remainder of the diets (minus alfalfa hay, supplement, and urea) consisted of DRC. Three scenarios were compared using dryrolled corn prices of $\$ 0.144, \$ 0.197$, and $\$ 0.250 / \mathrm{kg}$ of DM $(\$ 3.14, \$ 4.30$, and $\$ 5.47 /$ bushel at $86 \% \mathrm{DM}$ ).

Transportation costs were assumed to be $\$ 3.00 /$ loaded $1.61 \mathrm{~km}$ (mile) based on a 22,700 kg (as-is) load. Because costs for transporting a dry product from an ethanol plant have small effects on total costs, these analyses were conducted with the $96.6-\mathrm{km}$ trucking distance held constant.

Cattle prices leaving the feedlot were based on an assumed $\$ 90 / 45.4$ $\mathrm{kg}$ BW. Prices for cattle entering the feedlot vary inversely with corn prices to maintain relatively constant feeding margins. Therefore, feeder 
Table 2. Cattle performance and carcass characteristics for finishing steers when fed increasing levels of DDGS $^{1}$

\begin{tabular}{|c|c|c|c|c|c|c|c|c|}
\hline \multirow[b]{2}{*}{ Parameter } & \multicolumn{5}{|c|}{$\%$ DDGS } & \multirow[b]{2}{*}{ SEM } & \multicolumn{2}{|c|}{$P$-value } \\
\hline & 0 & 10 & 20 & 30 & 40 & & $\operatorname{Lin}^{2}$ & Quad $^{3}$ \\
\hline \multicolumn{9}{|l|}{ Performance } \\
\hline Initial BW, kg & 307 & 305 & 307 & 306 & 305 & 1.4 & 0.34 & 0.86 \\
\hline Final $\mathrm{BW},{ }^{4} \mathrm{~kg}$ & 553 & 562 & 575 & 566 & 559 & 7.4 & 0.46 & 0.07 \\
\hline Final $\mathrm{BW},{ }^{5} \mathrm{~kg}$ & 558 & 574 & 588 & 577 & 570 & 8.9 & 0.32 & 0.04 \\
\hline $\mathrm{DMI}, \mathrm{kg} / \mathrm{d}$ & 9.25 & 9.47 & 9.52 & 9.71 & 9.47 & 0.17 & 0.23 & 0.30 \\
\hline ADG, kg & 1.50 & 1.61 & 1.68 & 1.62 & 1.59 & 0.05 & 0.26 & 0.05 \\
\hline$G: F^{6}$ & 0.162 & 0.171 & 0.177 & 0.168 & 0.168 & 0.01 & 0.61 & 0.14 \\
\hline DDGS NE,$\%$ & - & 127 & 128 & 106 & 105 & 11.8 & 0.73 & 0.10 \\
\hline \multicolumn{9}{|c|}{ Carcass characteristics } \\
\hline $\mathrm{HCW},{ }^{7} \mathrm{~kg}$ & 351 & 362 & 370 & 364 & 359 & 5.6 & 0.32 & 0.04 \\
\hline Marbling score ${ }^{8}$ & 533 & 537 & 559 & 527 & 525 & 12.7 & 0.50 & 0.18 \\
\hline 12th rib fat, $\mathrm{cm}$ & 1.42 & 1.37 & 1.50 & 1.40 & 1.47 & 0.08 & 0.48 & 0.99 \\
\hline $\mathrm{LM}$ area, $\mathrm{cm}^{2}$ & 80.0 & 80.6 & 82.6 & 81.3 & 81.3 & 1.29 & 0.42 & 0.37 \\
\hline$Y^{9}$ & 3.36 & 3.36 & 3.49 & 3.38 & 3.42 & 0.09 & 0.62 & 0.63 \\
\hline
\end{tabular}

${ }^{1}$ DDGS = dry distillers grains plus solubles.

${ }^{2}$ Contrast for the linear effect of treatment $P$-value.

${ }^{3}$ Contrast for the quadratic effect of treatment $P$-value.

${ }^{4}$ Final live BW shrunk 4\% before slaughter

${ }^{5}$ Calculated from hot carcass weight, adjusted to a $63 \%$ common dress.

${ }^{6}$ Calculated as total gain over total dry matter intake.

${ }^{7} \mathrm{HCW}=$ hot carcass weight.

${ }^{8}$ USDA marbling score $450=$ Slight $^{50}, 500=$ Small ${ }^{0}, 550=$ Small $^{50}$.

9USDA YG calculated as $=2.50+6.35 \times$ fat thickness $(\mathrm{cm})+0.0017 \times \mathrm{HCW}(\mathrm{kg})-2.06 \times \mathrm{LM}$ area $\left(\mathrm{cm}^{2}\right)+0.2 \times \mathrm{KPH}(\% ;$ Boggs and

Merkel, 1993).

cattle prices were adjusted to reflect a $\$ 0$ profit in the corn-based diet.

Total feeding costs were calculated by combining feeding yardage costs, total feed consumed, diet costs, and transportation costs of hauling DDGS to the feedlot. The economic outcome was marginal returns per steer from feeding DDGS compared with feeding the DRC-based diet.

\section{RESULTS AND DISCUSSION}

\section{Feedlot Trial}

A quadratic relationship was observed for final BW $(P=0.04)$ and ADG $(P=0.05)$ as DDGS increased and replaced DRC (Table 2). The equation for ADG (determined by final BW) was $y=-0.0003 \mathrm{x}^{2}+$ $0.01411 \mathrm{x}+1.50$, where $\mathrm{y}=\mathrm{ADG}$ and $\mathrm{x}=$ inclusion percentage of DDGS.
Therefore, ADG was maximized at $23.5 \%$ inclusion of DDGS (DM basis) using the prediction equation. Steers fed 20\% DDGS had the heaviest final $\mathrm{BW}$ and highest $\mathrm{ADG}$ among all of the treatments in this experiment. Feeding any level of DDGS in this study resulted in numerically heavier final BW and higher ADG compared with the CON diet. These results indicate that higher inclusions of DDGS may not be optimum for cattle performance, but $\mathrm{ADG}$ remained greater than for steers fed a DRC diet. Increasing DDGS inclusion from 0 to $20 \%$ of diet DM increased $\mathrm{ADG}$ from 1.50 to $1.68 \mathrm{~kg}$. Intermediate $\mathrm{ADG}$ of 1.62 and 1.59 $\mathrm{kg}$ was observed for cattle fed 30 and $40 \%$ DDGS, respectively. These data agree with Gordon et al. (2002) who fed 15\% DDGS in steam-flaked corn diets and observed increased final
$\mathrm{BW}$ and $\mathrm{ADG}$. This same study resulted in similar final BW and ADG for feeding 30\% DDGS and the control, steam-flaked corn diet. Ham et al. (1994) compared DDGS at $40 \%$ of diet DM to a DRC-based diet and observed that ADG increased from 1.46 to $1.68 \mathrm{~kg}$. Benson et al. (2005) fed $0,15,25$, and $35 \%$ DDGS in crackedcorn based diets and reported a significant quadratic response for ADG as inclusion of DDGS increased. They found that feeding 25\% DDGS tended to increase ADG compared with feeding 0\% DDGS. Feeding 35\% DDGS numerically decreased ADG compared with feeding $25 \%$ DDGS, but $\mathrm{ADG}$ remained higher relative to feeding 0\% DDGS in a DRC diet.

No significant relationship (linear $P=0.23$, quadratic $P=0.30$ ) was observed for DMI as increasing levels of DDGS were fed. However, steers 
fed the control, corn-based diet had numerically the lowest DMI. This agreed with Mateo et al. (2004) as they observed the lowest numerical DMI for cattle fed 0\% DDGS at $9.09 \mathrm{~kg}$ compared with 10.5 and 10.6 $\mathrm{kg}$ for cattle fed 20 and 40\% DDGS, respectively. Benson et al. (2005) also observed that DMI was greater $(P<0.05)$ for cattle fed 15,25 , and $35 \%$ DDGS compared with the corn diet containing no DDGS. Stock et al. (1990) suggested that cattle fed high starch diets tend to experience more subacute acidosis challenges and they offset these situations by eating smaller meals more frequently. When by-products are included in finishing diets, starch levels are decreased. Therefore, it is possible that DMI may increase when including DDGS in diets due to less dietary starch and potentially less subacute acidosis.

Because DMI was not affected and ADG resulted in a significant quadratic relationship as DDGS inclusion increased, G:F approached a significant quadratic trend $(P=0.14)$ for increasing levels of DDGS. The equation for $\mathrm{G}: \mathrm{F}$ was $\mathrm{y}=-0.00002 \mathrm{x}^{2}$ $+0.000987 \mathrm{x}+0.162$, where $\mathrm{y}=\mathrm{G}: \mathrm{F}$ and $\mathrm{x}=$ inclusion percentage of DDGS. Optimum G:F was observed when steers were fed 20\% DDGS (0.177) in the experiment; however, solving for maximum G:F using the prediction equation suggests that $\mathrm{G}: \mathrm{F}$ is maximized at $24.7 \%$ inclusion (DM basis). Efficiency was the lowest for CON fed steers (0.162) and intermediate (0.168) for steers fed 30 and $40 \%$ DDGS. These feed efficiency results agree with other research conducted with DDGS. Vander Pol et al. (2005) observed numerically improved G:F as dietary DDGS increased from 10 to $20 \%$ of DM, and Ham et al. (1994) also reported increased G:F when steers were fed $40 \%$ DDGS compared with a cornbased diet. Numeric G:F increases were reported by Gordon et al. (2002) when they fed increasing levels of DDGS at 15,25 , and $35 \%$ of DM compared with a corn-based diet.
Steers fed 50\% DDGS were removed from the study following the grain adaptation phase. Only one steer exhibited signs of PEM and was removed from the study for the $40 \%$ DDGS treatment. Average analyzed $\mathrm{S}$ content for the DDGS used in this experiment was $1.01 \%$ (DM basis) and ranged from 0.87 to $1.20 \%$. Total dietary S increased as dietary inclusion of DDGS increased from $0.15 \%$ $\mathrm{S}$ in the CON diet to $0.50 \% \mathrm{~S}$ in the $40 \%$ DDGS diet. However, other than the one steer on $40 \%$ DDGS, no other treatments were impacted and no other steers appeared to be affected due to PEM. One additional steer death did occur on the 30\% DDGS treatment due to causes unrelated to the diet. The NRC (1996) suggests the maximum tolerable level of dietary $\mathrm{S}$ is $0.4 \%$ of diet DM. More recently, maximum tolerable levels of dietary S are suggested to be $0.3 \%$ $\mathrm{S}$ in grain-based diets, and $0.5 \% \mathrm{~S}$ in forage-based diets (NRC, 2005). It is clear that elevated S consumption by cattle can cause PEM (Gould, 1998); however, maximum tolerable levels from diets or different sources of $\mathrm{S}$ within diets is not well established because cattle fed 40\% DDGS in the current study were fed diets containing $0.5 \% \mathrm{~S}$ on average.

Calculated energy values relative to the CON diet resulted in a quadratic trend $(P=0.10$; Table 2$)$ as inclusion of DDGS was increased in diets from 0 to $40 \%$ of DM. Feeding 10 or $20 \%$ DDGS resulted in similar energy values of $127 \%$ of corn and feeding 30 and 40\% DDGS resulted in similar energy values of $106 \%$ of corn. The reasons for improved energy values when feeding DDGS compared with corn are not completely clear. In a review on the use of wet and dry milling byproducts, Stock et al. (2000) suggested that the improved energy responses from feeding by-products may be due to additional undegradable intake protein, higher fat content, or potential for reducing acidosis. Ham et al. (1994) proposed that replacing concentrate feeds with high fiber ingredients in feedlot diets decreases starch levels and reduces acidosis incidences, which may contribute to an improved energy response when feeding DDGS compared with corn. In a metabolism study, Vander Pol et al. (2008) observed that feeding $40 \%$ WDGS (DM basis) decreased average $\mathrm{pH}$ values and increased time spent with a $\mathrm{pH}$ under 5.6 , which is considered subacute acidosis. Therefore, the energy value improvement for distillers grains may not be due to controlling $\mathrm{pH}$ and subacute acidosis. However, they observed that feeding $40 \%$ WDGS increased propionate production, decreased the ratio of acetate to propionate, increased total tract fat digestion, and increased the amount of unsaturated fatty acids reaching the duodenum compared with a DRC-based diet or corn plus supplemental fat. Therefore, increased propionate production and fat digestion may explain the greater energy values when feeding distillers grains in finishing diets. In addition, distillers grains contains about 3 times the fat of DRC, thus providing more energy. Vander Pol et al. (2008) compared energy sources for cattle fed either WDGS or corn supplemented with added corn oil and observed that cattle fed WDGS consumed more feed, gained more weight, and were more efficient than cattle fed either corn or corn plus oil. They suggested that most of the improved energy response in WDGS was due to the fat content, but the source or availability of fat may be important as well.

A quadratic relationship for $\mathrm{HCW}$ was observed $(P=0.04)$ similar to final BW, but no other carcass characteristics were affected by DDGS inclusion level. Steers fed all of these treatments finished with similar degrees of fat thickness at $1.43 \mathrm{~cm}$, USDA marbling score of 536 (low Choice), and USDA calculated YG of 3.40. Benson et al. (2005) reported an increase in fat thickness for feeding steers 35\% DDGS compared with the corn-based diet, with no differences in carcass quality. Ham et al. (1994) and Vander Pol et al. (2005) did not observe any carcass characteristic 
differences other than HCW when feeding $40 \%$ or 10 and $20 \%$ DDGS, respectively. These studies indicate that feeding varying levels of DDGS in finishing diets results in similar or slightly greater fat thickness with no changes in carcass quality.

Visual bunk scores indicated that cattle fed 10, 20, and 30\% DDGS tended to move feed within the bunk (data not shown). Interestingly, cattle fed 40\% DDGS did not move their feed around as much as intermediate DDGS levels. It is important to note that proper mixing can be a challenge with use of DDGS at greater inclusions in the diet. Because DDGS is a dry, less bulky feed, care should be used when feeding high levels to ensure sorting does not occur, as cattle may choose to sort out the DDGS to consume it first.

\section{Economic Analysis}

Predicted days on feed, transportation costs to the feedlot, and returns for feeding 10, 20, 30, and 40\% DDGS (DM basis) are presented in Table 3. Days on feed, calculated from $\mathrm{ADG}$ and $\mathrm{BW}$, responded quadratically with a decrease and then increase as DDGS level increased. Days on feed were the greatest for CON fed steers at $166 \mathrm{~d}$ and lowest for $20 \%$ DDGS at $149 \mathrm{~d}$. This decrease in days on feed calculated to a $\$ 3.93$ savings for a steer fed $20 \%$ DDGS compared with CON over the feeding period due to decreased yardage costs.

Table 3. Economic analysis for predicting DDGS ${ }^{1}$ returns

\begin{tabular}{|c|c|c|c|c|c|}
\hline \multirow[b]{2}{*}{ Item } & \multicolumn{5}{|c|}{$\%$ DDGS } \\
\hline & $0 \%$ & $10 \%$ & $20 \%$ & $30 \%$ & $40 \%$ \\
\hline Predicted DMI, ${ }^{2} \mathrm{~kg} / \mathrm{d}$ & 9.25 & 9.48 & 9.60 & 9.62 & 9.52 \\
\hline Predicted G:F² & 0.161 & 0.169 & 0.172 & 0.171 & 0.164 \\
\hline Calculated ADG, ${ }^{3} \mathrm{~kg} / \mathrm{d}$ & 1.49 & 1.60 & 1.65 & 1.64 & 1.56 \\
\hline Calculated DOF, ${ }^{4} \mathrm{~d}$ & 166 & 154 & 149 & 150 & 157 \\
\hline DDGS transportation, ${ }^{5}$ \$/head & 0 & 1.34 & 2.63 & 3.98 & 5.51 \\
\hline Nonfeeding yardage costs, ${ }^{6} \$ /$ head & 39.34 & 36.56 & 35.41 & 35.67 & 37.39 \\
\hline Feeding yardage costs, ${ }^{7} \$ /$ head & 19.67 & 18.71 & 18.32 & 18.44 & 19.09 \\
\hline \multicolumn{6}{|c|}{ Marginal return with DDGS priced at $100 \%$ of 3 different corn prices, ${ }^{8,9} \$ /$ head } \\
\hline$\$ 0.144 / \mathrm{kg}$ & - & 16.68 & 22.96 & 19.43 & 6.67 \\
\hline$\$ 0.197 / \mathrm{kg}$ & - & 19.62 & 27.01 & 22.98 & 8.00 \\
\hline$\$ 0.250 / \mathrm{kg}$ & - & 22.56 & 31.07 & 26.53 & 9.33 \\
\hline \multicolumn{6}{|c|}{ Marginal return with DDGS priced at $80 \%$ of 3 different corn prices,,$^{8,9} \$ /$ head } \\
\hline$\$ 0.144 / \mathrm{kg}$ & - & 17.80 & 26.43 & 25.42 & 15.25 \\
\hline$\$ 0.197 / \mathrm{kg}$ & - & 22.17 & 33.08 & 32.50 & 20.81 \\
\hline$\$ 0.250 / \mathrm{kg}$ & - & 26.53 & 39.71 & 39.52 & 26.29 \\
\hline
\end{tabular}

${ }^{1}$ DDGS = dry distillers grains plus solubles.

${ }^{2}$ Predicted by DMI and G:F equations derived from experiment results.

${ }^{3}$ Calculated from predicted DMI and G:F values.

${ }^{4} \mathrm{DOF}=$ days on feed; calculated with ADG combined with feeder and market cattle weights.

${ }^{5}$ Costs needed to transport DDGS $96.6 \mathrm{~km}$ from ethanol plant to feedlot.

${ }^{6}$ Calculated based on two-thirds of $\$ 0.35 /$ head daily yardage cost.

${ }^{7}$ Calculated based on one-third of $\$ 0.35 /$ head daily yardage cost.

${ }^{8}$ Corn prices expressed as $\$ / \mathrm{kg}$ of DM and equate to $\$ 3.14, \$ 4.30$, and $\$ 5.47$ per bushel (86\% DM).

${ }^{9}$ Calculated as the difference between profit or loss per animal fed DDGS compared with dry-rolled corn-fed cattle.
Costs per steer for transporting DDGS from an ethanol plant to the feedlot at $96.6 \mathrm{~km}$ over the feeding period were $\$ 1.34, \$ 2.63, \$ 3.98$, and $\$ 5.51$ for $10,20,30$, and $40 \%$ DDGS, respectively. Transportation costs for DDGS increased feeding costs but decreased days on feed, which led to less total intake over the feeding period, resulting in decreased feeding costs. Although corn price changed in these scenarios, feeding costs were consistently the greatest for steers fed CON and the lowest for steers fed $20 \%$ DDGS whether DDGS is priced at 80 or $100 \%$ of corn price. Regardless of corn prices, cattle fed any level of DDGS from 10 to $40 \%$ resulted in greater marginal returns per steer compared with feeding predominately DRC, and profit increased across all levels of DDGS as corn prices increased. Similarly, marginal returns increased as DDGS price decreased relative to corn, as expected. However, this did not change the optimal inclusion of DDGS, but did result in greater returns when DDGS was included at higher inclusions (30 and $40 \%$ ). The economic optimum level of DDGS was $20 \%$ of diet DM, with marginal returns of $\$ 23$ to $\$ 31$ per steer or $\$ 26$ to $\$ 40$ more per steer compared with steers fed corn-based diets when DDGS was priced at 100 or $80 \%$ of corn price, respectively. Return was actually greater relative to corn-based diets as corn became more expensive; however, profits would decrease if initial steer prices were not decreased.

\section{IMPLICATIONS}

Feeding increasing levels of DDGS in place of corn increased $\mathrm{ADG}$ and G:F quadratically. The calculated optimum level of DDGS inclusion for performance is 23 to $24 \%$ of diet DM. Economic marginal returns for feeding DDGS from 0 to $40 \%$ of diet DM increased quadratically, with the optimum inclusion at $20 \%$. Economic returns remained greater when including 30 and 40\% DDGS in feedlot diets compared with a DRC diet, but depends on price relative to corn. 
These performance and economic results suggest that the optimum DDGS inclusion level was $20 \%$ of diet DM, but greater inclusions may be fed to allow greater use of DDGS from increased ethanol production.

\section{LITERATURE CITED}

Benson, C.S., C.L. Wright, K.E. Tjardes, R.E. Nicolai, and B.D. Rops. 2005. Effects of feeding varying concentrations of dry distiller's grains with solubles to finishing steers on feedlot performance, nutrient management and odorant emissions. South Dakota Beef Rep. 2005-13:59.

Boggs, D. L., and R. A. Merkel. 1993. Beef carcass evaluation, grading, and pricing. p. 105 in Live Animal Carcass Evaluation and Selection Manual. D. L. Boggs and R. A. Merkel, ed. Kendel/Hunt Publishing Co., Dubuque, IA.

Erickson, G., and T. Klopfenstein. 2002. Distillers grains for beef cattle. Proc. North Central Distillers Grains Conf., Prior Lake, MN.

Gordon, C. M., J. S. Drouillard, J. Gosch, J. J. Sindt, S. P. Montgomery, J. N. Pike, T. J. Kessen, M. J. Sulpizio, M. F. Spire, and J. J. Higgins. 2002. Dakota Gold-brand dried distiller's grains with solubles: Effects on finishing performance and carcass char- acteristics. p. 27 in Beef Cattle Res. Rep., Kansas State Univ., Manhattan.

Gould, D. H. 1998. Polioencephalomalacia. J. Anim. Sci. 76:309.

Ham, G. A., R. A. Stock, T. J. Klopfenstein, E. M. Larson, D. H. Shain, and R. P. Huffman. 1994. Wet corn distillers byproducts compared with dried corn distillers grains with solubles as a source of protein and energy for ruminants. J. Anim. Sci. 72:3246

Mateo, K.S., K.E. Tjardes, C.L. Wright, T.J. Koger, and B.D. Rops. 2004. Evaluation of feeding varying levels of wet distillers grains with solubles as compared to dry distillers grains with solubles to finishing steers. South Dakota Beef Rep. 2004-03: 14.

NRC. 1996. Nutrient Requirements of Beef Cattle. Update 2000. Natl. Acad. Press, Washington, DC.

NRC. 2005. Mineral Tolerance of Animals. 2nd ed. Natl. Acad. Press, Washington DC.

Owens, F. N., M. A. Hinds, and D. W. Rice. 2002. Methods for calculating diet energy values from feedlot performance of cattle. J. Anim. Sci. 80(Suppl. 1):273.

Stock, R. A., J. M. Lewis, T. J. Klopfenstein, and C. T. Milton. 2000. Review of new information on the use of wet and dry milling feed by-products in feedlot diets. J. Anim. Sci. http://www.asas.org/symposia/proceedings/0924.pdf. Accessed April 4, 2007.
Stock, R. A., M. H. Sindt, J. C. Parrott, and F. K. Goedeken. 1990. Effects of grain type, roughage level and monensin level on finishing cattle performance. J. Anim. Sci. 68:3441

Tinsdale, S. L., W. L. Nelson, and J. D. Beaton. 1985. Soil Fertility and Fertilizers. 4th ed. Macmillan Publishing Co. New York, NY.

Vander Pol, K. J., G. E. Erickson, and T. J. Klopfenstein. 2005. Degradable intake protein in finishing diets containing dried distillers grains. Nebraska Beef Cattle Rep. MP 83-A:42.

Vander Pol, K. J., G. E. Erickson, T. J. Klopfenstein, M. A. Greenquist, and T. Robb. 2006a. Effect of dietary inclusion of wet distillers grains on feedlot performance of finishing cattle and energy value relative to corn. Nebraska Beef Rep MP 88-A:51.

Vander Pol, K. J., G. E. Erickson, T. J. Klopfenstein, and D. R. Mark. 2006b. Economic optimum use of wet distillers grains in feedlots. Nebraska Beef Cattle Rep. MP 88-A:54.

Vander Pol, K. J., M. K. Luebbe, G. I. Crawford, G. E. Erickson, and T. J. Klopfenstein. 2008. Performance and digestibility characteristics of finishing diets containing distillers grains, composites of corn-processing coproducts, or supplemental corn oil. J. Anim. Sci. (accepted). 